\title{
MIKROENKAPSULASI MINYAK ATSIRI DAUN CENGKEH (SYZYGIUM AROMATICUM) DENGAN ENKAPSULAN GELATIN KERBAU MENGGUNAKAN METODE SPRAY DRYING
}

\section{Microencapsulation of Clove Leaf Essential Oil (Syzygium aromaticum) with Buffalo Gelatin Encapsulant Using Spray Drying Method}

\author{
Masrukan ${ }^{1}$, Umar Santoso $^{2}$ \\ ${ }^{1}$ Program Studi Teknologi Pangan - Universitas Widya Mataram \\ Dalem Mangkubumen KT III/237 Yogyakarta \\ 2.Departemen Teknologi Pangan dan Hasil Pertanian - FakultasTeknologi Pertanian - \\ Universitas Gadjah Mada \\ Jl. Flora No. 1, Bulaksumur, Yogyakarta 55281 \\ *Penulis Korespondensi: email: mrukan@gmail.com
}

Disubmit: 18 Agustus 2018 Direvisi: 29 Maret 2019 Diterima: 30 Maret 2019

\begin{abstract}
ABSTRAK
Gelatin merupakan protein yang diperoleh dari hidrolisis parsial kolagen yang ditemukan di dalam kulit, tulang, dan jaringan ikat hewan. Pada umumnya, gelatin diekstrak dari kulit sapi dan babi yang mempunyai permsalahan terkait isu penyakit sapi gila dan kehalalanya. Tujuan penelitian ini adalah untuk mengetahui karakteristik gelatin yang diesktrak dari kulit kerbau dan aplikasinya sebagai enkapsulan pada mikroenkapsulasi minyak atsiri daun cengkeh. Gelatin kulit kerbau diekstrak menggunakan larutan asam klorida (Tipe A) $1 \%, 70^{\circ} \mathrm{C}$ selama 5 jam. Gelatin kulit kerbau diaplikasikan sebagai enkapsulan pada mikroenkapsulasi (spray drying) minyak atsiri daun cengkeh menggunakan rancangan acak lengkap (RAL) dengan faktor perbedaan konsentrasi gelatin $(5 \%, 7.5 \%$, dan $10 \%)$ dan rasio antara minyak atsiri daun cengkeh dengan gelatin (1:10, 1:15 dan 1:20). Karakteristik gelatin kulit kerbau mempunyai kadar air $7.4 \%$, kadar abu $0.06 \%$, kadar lemak $0.04 \%$, kadar protein $89.1 \%$, viskositas $4.8 \mathrm{cP}$ dan kekuatan gel gelatin $155.39 \mathrm{~g}$ Bloom. Karakteristik mikrokapsul minyak atsiri daun cengkeh mempunyai kelarutan $79.79 \%$, total minyak $1.10 \mathrm{mg} / \mathrm{ml}$, minyak terperangkap $0.87 \mathrm{mg} / \mathrm{ml}$, dan minyak dipermukaan $0.23 \mathrm{mg} / \mathrm{ml}$. Morfologi mikrokapsul minyak atsiri daun cengkeh berbentuk oval dan tidak beraturan
\end{abstract}

Kata kunci: Ekstraksi; Kulit kerbau; Kolagen; Mikrokapsul

\begin{abstract}
Gelatin is protein obtained from partial hydrolysis of collagen contained in the animal skin, bone, connective tissue. In general, gelatin is extracted from cow and pig skin that have problems related to the issue of mad cow disease and halal. In the present study, gelatin was extracted from buffalo skin collagen and then applied as wall material in microencapsulation of clove leaves essential oil. Characteristics of buffalo skin gelatin and its application in microencapsulation of clove leaves essential oil were studied. Buffalo skin gelatin was extracted using $1 \%$ hydrochloric acid (type A) at $70^{\circ} \mathrm{C}$ for 5 hours. Gelatin is used as wall material in clove leaf essential oil microencapsulation with spray drying using a completely randomized design (CRD) with different concentrations of gelatin (5\%, 7.5\%, and 10\%) and the ratio between clove leaf essential oil and gelatin. The results showed that gelatin have yield $56.73 \%$, moisture content $7.4 \%$, ash content $0.06 \%$, protein $89.1 \%$, viscosity $4.7 \mathrm{cP}$, and gel strength $155.39 \mathrm{~g}$ Bloom. Microcapsule of clove leaves oil have solubility $79.72 \%$, total oil content $1.10 \mathrm{mg} / \mathrm{ml}$, trapped oil $0.87 \mathrm{mg} / \mathrm{ml}$, and surface oil 0.23 $\mathrm{mg} / \mathrm{ml}$. Morphology of microcapsule have oval and irregular shape of granules.
\end{abstract}

Keyword: Buffalo skin; Collagen; Extraction; Microcapsule 


\section{PENDAHULUAN}

Minyak cengkeh merupakan minyak atsiri yang berasal dari tanaman cengkeh (Syzigium aromaticum), yang termasuk dalam famili Myrtaceae, yang banyak ditanam di Indonesia, India dan Madagaskar (Alma et al., 2007). Minyak cengkeh telah banyak dimanfaatkan sebagai antibakteri (Jasna Ivanovic et al., 2008), aktivitas antioksidan, dan antikarsinogen (Ilhami Gulci et al., 2012).

Meskipun banyak digunakan dalam berbagai bidang, minyak atsiri rentan terhadap suhu tinggi, oksidasi, sinar UV dan kelembaban (Petrovic et al., 2010 dan Calvo et al., 2012). Salah satunya adalah kerusakan oksidatif yang dapat menyebabkan terbentuknya off-flavor, stabilitas umur simpan menurun, dan berpengaruh pada sifat sensoris (Velasco et al., 2003), sehingga diperlukan solusi untuk mengatasi permasalahan tersebut.

Mikroenkapsulasi merupakan salah satu teknik untuk melindungi minyak atsiri dari kerusakan akibat dari kondisi proses pengolahan dan penyimpanan, dengan cara memperlambat evaporasi minyak atsiri. Mikroenkapsulasi dapat melindungi bahan inti (core) yang semula berbentuk cair menjadi bentuk padatan sehingga mudah dalam penanganannya serta dapat melindungi bahan inti dari kehilangan flavor (Soottitantawat et al., 2003; dan Gharsallaoui et al.,2007;). Salah satu metode mikroenkapsulasi yang paling banyak digunakan adalah spray drying. Beberapa faktor yang dapat mempengaruhi retensi bahan aktif dalam mikrokapsul hasil spray drying diantaranya adalah jenis enkapsulan, konsentrasi enkapsulan dan rasio antara minyak atsiri dengan enkapsulan.

Gelatin merupakan campuran dari peptida dan protein yang diperoleh dari hidrolisis parsial kolagen yang ditemukan di dalam kulit, tulang, dan jaringan ikat hewan. Gelatin digunakan sebagai enkapsulan karena sifat biodegradasinya, biokompatibilitas, tidak beracun, murah, larut air dan pembentuk film serta kemampuan pengemulsinya (Polin S et al., 2014). Gelatin kulit kerbau diekstraksi dari sumber kolagen kulit kerbau. Persentase berat kulit kerbau sekitar $11.5 \%$, sedangkan kulit sapi $9 \%$ dari bobot hidup, sehingga kandungan kolagen dalam kulit kerbau lebih tinggi dari kulit sapi. Adanya hukum syariat islam yang mewajibkan pengikutnya untuk mengkonsumsi sesuatu yang jelas kehalalannya serta isu-isu lain dari hewan sapi tentang maraknya berita tentang penyakit sapi gila (mad cow disease) atau Bovine Spongioform Encephalopathy (BSE), maka gelatin yang diekstrak dari kulit kerbau sebagai alternatif pembuatan gelatin yang dapat diterima seluruh masyarakat. Gelatin digunakan sebagai enkapsulan telah dilaporkan pada mikroenkapsulasi minyak atsiri kamper (Chang et al., 2006), minyak atsiri serai (Hsieh et al., 2006), dan minyak atsiri pappermin (Dong et al., 2008).

Berdasarkan uraian tersebut, maka dalam penelitian ini akan dikaji penggunaan gelatin kulit kerbau sebagai enkapsulan pada mikroenkapsulasi minyak atsiri daun cengkeh dengan menggunakan metode spray drying.

\section{METODE}

Bahan yang digunakan pada penelitian ini adalah minyak atsiri daun cengkeh (Syzygium aromaticum) diperoleh dari petani di Samigaloh, Kulonprogo, Yogyakarta. Sedangkan kulit kerbau diperoleh dari hasil samping sentra industri kerajinan wayang di daerah Pucung, Imogiri, Bantul, Yogyakarta dengan ketebalan $0.5 \mathrm{~cm}$. Kulit kerbau yang diperoleh dalam kondisi kering (kadar air $12 \%)$.

Alat-alat yang digunakan dalam ekstraksi gelatin adalah beker gelas, erlenmeyer $500 \mathrm{ml}$, dan shaker waterbath (Yamato tipe BT300). Peralatan yang digunakan untuk mekroenkapsulasi minyak atsiri daun cengkeh adalah Turrax homogenizer (IKA-T 50 Basic, Artisan Tech Group, Champaign, USA) dan pengering semprot (Spray Dryer, SD-Basic Lab Plant, West Yorkshire, UK).

\section{Rancangan Penelitian}

Penelitian ini dilakukan menggunakan Rancangan Acak Lengkap (RAL), dengan faktor perbedaan konsentrasi gelatin $(5 \%, 7.5 \%$, dan $10 \%)$ dan rasio antara minyak atsiri daun cengkeh dengan gelatin (1:10, 1:15 dan 1:20). Gelatin kerbau yang terpilih akan dibandingkan dengan gelatin komersial.

\section{Ekstraksi gelatin}

Proses ekstraksi gelatin berdasarkan tipe A, yaitu menggunakan larutan asam klorida didasarkan pada Gomez-Guillen dan Montero (2001). Kulit kerbau dicuci dengan air dan dipotong (1-2 cm), kemudian di- 
lakukan perebusan selama 25-30 menit pada suhu $60-70{ }^{\circ} \mathrm{C}$. kulit kerbau direndam dengan larutan asam klorida 1\% selama 24 jam. Selanjutnya kulit kerbau dinetralkan $\mathrm{pH}$-nya. Setelah itu diekstraksi dalam waterbath pada suhu $70^{\circ} \mathrm{C}$ selama $5 \mathrm{jam}$, dengan perbandingan kulit kerbau dengan air (1:3). Filtrat yang diperoleh dikeringkan pada suhu $55^{\circ} \mathrm{C}$ selama \pm 48 jam.

\section{Mikroenkapsulasi Minyak Atsiri Daun Cengkeh}

Mikrokapsul dibuat dengan mencampurkan minyak atsiri daun cengkeh dengan larutan gelatin kulit kerbau pada berbagai konsentrasi (k) yaitu 5\%, 7.5\% dan 10\% dengan rasio minyak atsiri daun cengkeh dengan gelatin $(\mathrm{r})$ yaitu 1:10, 1:15 dan1:20. Selanjutnya dilakukan homogenisasi dengan homogenizer $5200 \mathrm{rpm}$ selama 3 menit, sehingga terbentuk mikroemulsi.

Selanjutnya mikroenkapsulasi dilakukan dengan memasukan mikroemulsi $100 \mathrm{ml}$ kedalam pengering semprot pada suhu inlet $100{ }^{\circ} \mathrm{C}$ dan outlet $80^{\circ} \mathrm{C}$.

\section{Metode Analisis \\ Rendemen}

Besarnya rendemen gelatin kulit kerbau dapat diperoleh dengan menggunakan Persamaan 1.

Rendemen $=($ Berat kulit gelatin $) /($ Berat kulit kerbau ) x $100 \%$

\section{Viskositas (British Standars 757, 1975)}

Gelatin $6.67 \%(\mathrm{~b} / \mathrm{v})$ dilarutkan dalam air pada suhu $60{ }^{\circ} \mathrm{C}$, diukur viskositasnya menggunakan alat viscometer vt-4. Nilai viskositas dinyatakan dalam satuan centipoise $(\mathrm{cP})$.

\section{Kekuatan Gel (Gomez-Guillen, 2001)}

Larutan gelatin dengan konsentrasi $6.67 \%(\mathrm{~b} / \mathrm{v})$ dilarutkan dalam air pada suhu $60^{\circ} \mathrm{C}$. Selanjutnya, larutan dituang dalam standard bloom jars (botol dengan diameter 58-60 mm, tinggi $85 \mathrm{~mm}$ ), selanjutnya diinkubasi pada suhu $9-10{ }^{\circ} \mathrm{C}, 17-18$ jam. Kekuatan gel gelatin diukur menggunakan alat TA-XT plus Texture Analyzer pada kecepatan probe $1 \mathrm{~mm} /$ detik dengan kedalaman $4 \mathrm{~mm}$ dengan diameter plunger yang digunakan adalah $12.7 \mathrm{~mm}$. Kekuatan gel (g Bloom):gaya maks $\left(\mathrm{g} / \mathrm{mm}^{2}\right)$ x luas permu- kaan plunger $\left(\mathrm{mm}^{2}\right)$. Luas permukaan plunger dengan $(r=6.35)$ adalah $126.728 \mathrm{~mm}^{2}$.

Analisis Proksimat dan Profil Asam Amino Analisa proksimat (kadar air, abu, protein, dan lemak) mengacu pada metode dari AOAC (1995), sedangkan profil asam amino menggunakan HPLC. Kondisi HPLC diset pada suhu $38^{\circ} \mathrm{C}$; kolom menggunakan Eurospher 100-5 C18, $250 \times 4.6 \mathrm{~mm}$ with precolumn P/N: 11115Y535; kecepatan alir menggunakan sistem linear gradient $(1.5 \mathrm{ml} /$ menit) dengan batas tekanan 3000 psi; dengan eluen (Eluen : $\mathrm{A}=$ Buffer asetat $0.01 \mathrm{M}$ pH 5.9, B= Metanol: buffer asetat $001 \mathrm{M} \mathrm{pH}$ 9,5:THF-> 80: 15: 5), Ext: 340, Em: 450 nm.

\section{Total Minyak (Eugenol) Mikrokapsul (Ujwala et al., 2011)}

Mikrokapsul minyak atsiri daun cengkeh diekstrak dengan menggunakan lautan metanol. Filtrat dari mikrokapsul ditera dengan spektofotometri UV dengan panjang gelombang $281 \mathrm{~nm}$, dengan metanol sebagai larutan blanko.

\section{Minyak Atsiri di Permukaan Mikrokapsul (Yuliani et al., 2007)}

$0.5 \mathrm{~g}$ mikrokapsul dalam erlenmeyer diekstrak dengan $6.7 \mathrm{ml}$ heksana (SigmaAldrich), kemudian dikocok dan disaring menggunakan kertas Whatman No. 1. Filtrat mikrokapsul ditera dengan spektofotometri UV dengan panjang gelombang $281 \mathrm{~nm}$, dengan metanol sebagai larutan blanko.

\section{Kelarutan Mikrokapsul (Chen dan Jane, 1994)}

Sampel sebanyak $1 \mathrm{~g}$ mikrokapsul dilarutkan dalam $100 \mathrm{ml}$ aquadest, diaduk menggunakan homogenizer (Ultraturrax T50 Basic IKA Werke, Germany) 4000 rpm, 2 menit. Selanjutnya, suspensi mikrokapsul ditempatkan pada botol sentrifuse, lalu disentrifuse pada $4000 \mathrm{rpm}$ selama 15 menit. Sebanyak $25 \mathrm{ml}$ supernatan diambil kemudian ditempatkan dalam cawan petri, selanjutnya dilakukan pengeringan dalam oven $\left(105^{\circ} \mathrm{C}\right)$.

Kelarutan $(\%)=($ Berat akhir $\times 4) /$ (Berat awal ) $\times 100 \%$

Morfologi Mikrokapsul (Caliskan dan Dirim, 2013)

Morfologi mikrokapsul minyak atsiri 
daun cengkeh diamati menggunakan Scanning Electron Microscope (SEM type JSM-6510 LA, USA). Mikrokapsul ditempelkan menggunakan carbontape pada SEM stubs (tipe JEC-3000 FC) atau dudukan sampel dengan diameter $10 \mathrm{~mm}$ menggunakan pita perekat dua sisi. Sampel dilapisi dengan platina dan dilihat pada perbesaran 100 hingga 10000 kali dengan voltase $10 \mathrm{kV}$.

\section{Analisis Data}

Data yang diperoleh dari hasil penelitian akan dianalisis secara statistik untuk mengetahui adanya perbedaan antar perlakuan dengan menggunakan uji ANOVA Pada $a=5 \%$ menggunakan SPSS 16 Apabila ada perbedaan, maka dilanjutkan dengan uji Tukey (BNJ) untuk menentukan nilaim kritis uji perbandingan.

\section{HASIL DAN PEMBAHASAN}

\section{Karakteristik Gelatin Kulit Kerbau}

Hasil pengukuran terhadap sifat fisik dan kimia gelatin kulit kerbau dengan gelatin porcine sigma disajikan pada Tabel 1 . Kadar air gelatin kulit kerbau adalah 7.42\% kandungan air tersebut lebih rendah jika dibandingkan dengan gelatin porcine sebesar $12.42 \%$. Rendahnya kadar air gelatin kulit kerbau diduga karena pengaruh pengeringan yang terlalu lama, sehingga banyak air yang teruapkan. Kadar protein gelatin kulit kerbau adalah $89.90 \%$, nilainya tidak jauh berbeda dari gelatin porcine, yaitu sebesar $90.36 \%$. Apabila dibandingkan dengan gelatin sapi kadar protein gelatin kulit kerbau lebih tinggi. Tingginya kadar protein pada gelatin kulit kerbau diduga diakibatkan oleh sumber kolagen yang berasal dari kulit hewan mamalia, yang diketahui bahwa memiliki kandungan protein yang tinggi. Kadar abu gelatin kulit kerbau adalah $0.06 \%$, nilai tersebut lebih rendah jika di gelatin porcine $0.19 \%$. Begitupun juga pada kadar lemak gelatin kulit kerbau, lebih rendah dari gelatin porcine.

Kekuatan gel gelatin kulit kerbau adalah 140.26 g Bloom, nilai tersebut lebih rendah dibanding dengan gelatin porcine, yaitu 291.37 g. Nilai kekuatan gel gelatin berhubungan dengan adanya kandungan hidroksiprolin dan lisin pada gelatin kulit kerbau. Makin besar jumlah hidroksiprolinnya, maka makin tinggi kemampuannya untuk membentuk struktur triple heliks yang sangat penting dalam kestabilan struktur gel gelatin (Gomez- Guillen et al., 2001). Menurut Liu et al. (2008), bahwa tingginya kandungan lisin juga berperan dalam pembentukan struktur cross-linking pada molekul gelatin.

Viskositas gelatin kulit kerbau adalah $4.83 \mathrm{cP}$. Nilai tersebut lebih rendah dari gelatin porcine, yaitu $7.5 \mathrm{cP}$. Menurut (Gudmunsson dan Hasteinson, 1997; Pranoto et al., 2011), viskositas gelatin berkaitan dengan panjang pendeknya rantai asam amino. Panjang rantai asam amino berhubungan dengan berat molekul. Semakin panjang rantai asam amino, semakin berat molekul gelatin sehingga viskositas gelatin semakin tinggi.

\section{Profil Asam Amino Gelatin}

Komposisi asam amino dalam gelatin bervariasi tergantung pada sumber kolagen tersebut, spesies hewan penghasil dan jenis kolagen. Hasil pengujian komposisi asam amino gelatin kulit kerbau dapat dilihat pada Tabel 2.

Pada penelitian ini kandungan asam amino, glisin dan prolin gelatin kulit kerbau yaitu masing-masing $22.15 \pm 0.57 \%$ dan $11.2 \pm 0.08 \%$, sedangkan asam amino hidroksi prolin tidak terdeteksi. Glisin, Prolin dan hidroksiprolin sangat berperan dalam menentukan kekuatan gel. Glisin merupakan asam amino pembatas prolin dan hidoksiprolin. Glisin termasuk asam amino polar tak bermuatan, dan glutamat merupakan asam amino polar bermuatan negatif bersifat asam dan alanin termasuk nonpolar. Makin besar persentase glisin maka daya ikat gelatin makin baik karena asam amino glisin berikatan dengan air.

\section{Kelarutan Mikrokapsul Minyak Atsiri Daun Cengkeh}

Kelarutan mikrokapsul merupakan salah satu parameter terpenting untuk diketahui karena berkaitan dengan penggunakan mikrokapsul dalam sebuah produk. Rasio antara minyak daun cengkeh dengan gelatin sebagai enkapsulan yang berbeda akan berpengaruh terhadap kelarutan mikrokapsul yang dihasilkan. Kelarutan mikrokapsul minyak daun cengkeh dapat dilihat pada Gambar 1.

Kelarutan mikrokapsul pada penelitian ini mempunyai kisaran nilai antara $72.98-82.3 \%$. Konsentrasi gelatin 5\% yang digunakan sebagai enkapsulan pada pembuatan mikrokapsul mempunyai kelarutan 
Jurnal Teknologi Pertanian Vol. 20 No. 1 [April 2019] 45-52

Mikroenkapsulasi Minyak Atsiri Daun Cengkeh [Masrukan dkk]

Tabel 1. Sifat fisik dan kimia gelatin kulit kerbau, sapi dan procine

\begin{tabular}{lccc}
\hline Parameter & Gelatin kulit kerbau & Gelatin sapi & Gelatin procine \\
\hline Kadar air $(\%)$ & 7.42 & 14.34 & 12.42 \\
Kadar protein $(\mathrm{db} \%)$ & 89.9 & 72.05 & 90.36 \\
Kadar lemak $(\mathrm{db} \%)$ & 0.04 & 1.03 & 0.08 \\
Kadar abu $(\mathrm{db} \%)$ & 0.06 & 2.31 & 0.19 \\
Kekuatan gel $(\mathrm{g}$ Bloom $)$ & 140.72 & 184.35 & 291.37 \\
Viskositas $(\mathrm{cP})$ & 4.83 & 5 & 7.5 \\
Titik leleh $\left({ }^{\circ} \mathrm{C}\right)$ & 27.4 & 25.4 & 29.3 \\
\hline
\end{tabular}

Tabel 2. Profil asam amino gelatin kerbau

\begin{tabular}{lc}
\hline Asam amino & Satuan $\mathbf{( \% )}$ \\
\hline Asam aspartat & 5.45 \\
Asam glutamat & 9.95 \\
Treonin & 3.6 \\
Serin & 3.9 \\
Sistein & 2.35 \\
Histidin & 3.45 \\
Glysin & 22.15 \\
Alanin & 11.07 \\
Arginin & 7.80 \\
Tyrosin & 0.95 \\
Methionin & 1.90 \\
Valin & 2.75 \\
Phenilalanin & 2.70 \\
Isoleusin & 2.02 \\
Leusin & 4.05 \\
Lysin & 3.68 \\
Prolin & 11.2 \\
\hline
\end{tabular}

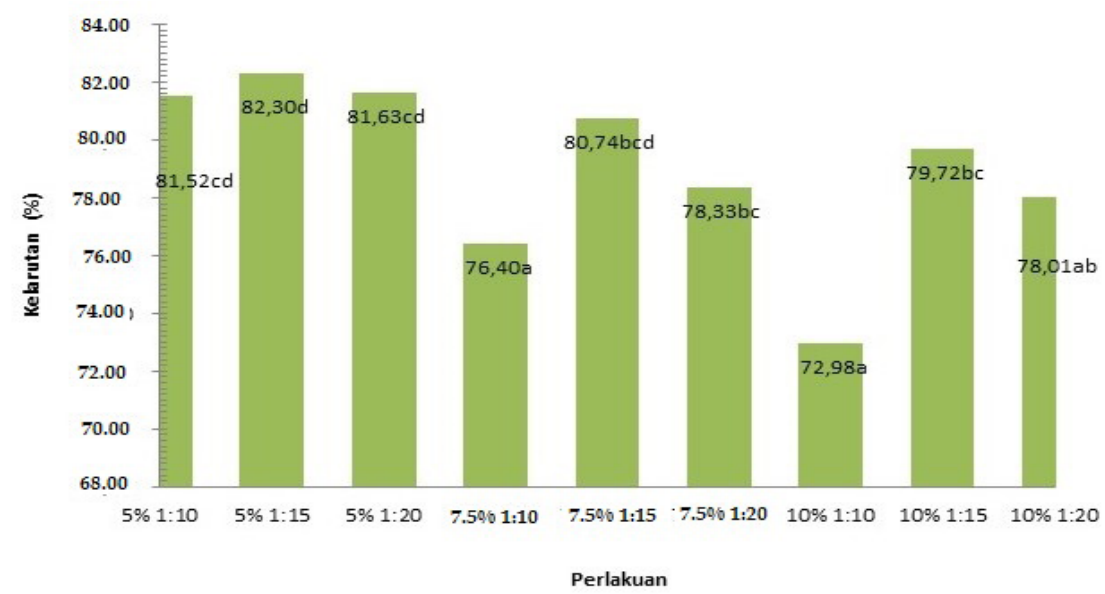

Gambar 1. Kelarutan mikrokapsul minyak daun cengkeh. Huruf yang berbeda di belakang angka pada histogram menunjukkan perbedaan nyata $(\mathrm{P}<0.05)$ 


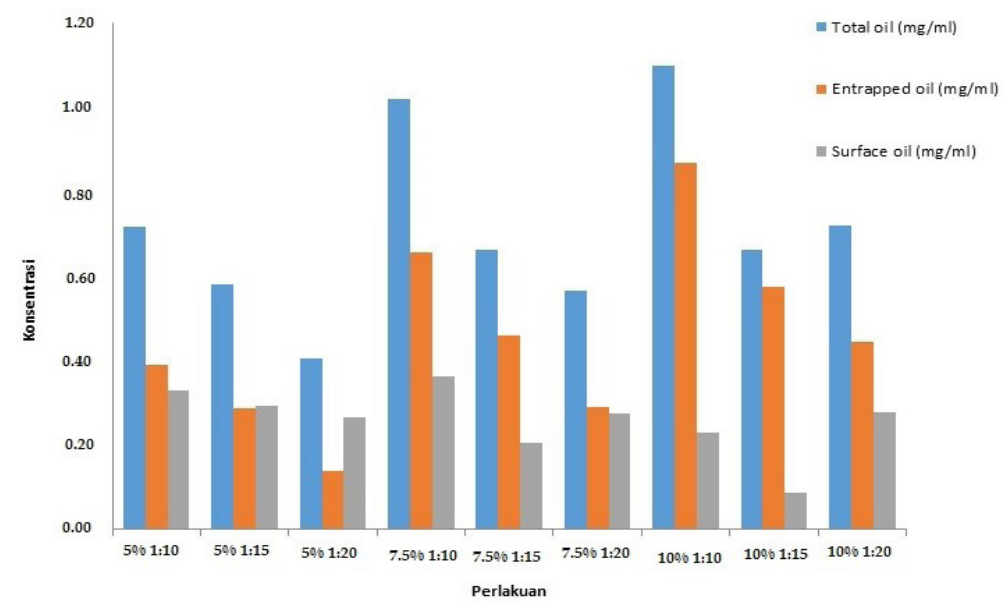

Gambar 2. TO, EO dan SO mikrokapsul minyak daun cengkeh. Huruf yang berbeda di belakang angka pada histogram menunjukkan perbedaan nyata $(\mathrm{P}<0.05)$
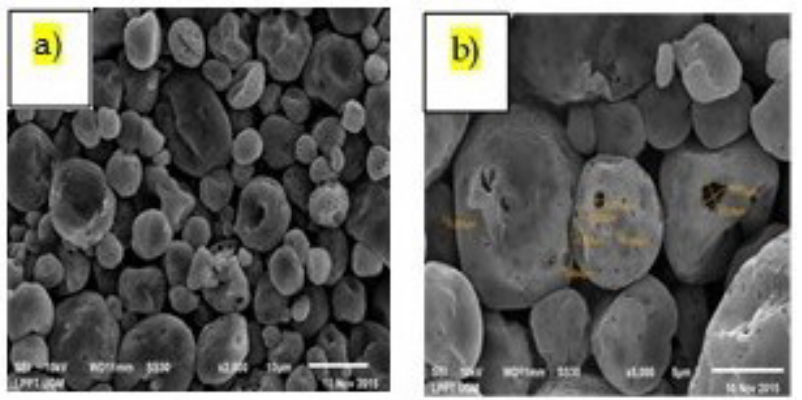

Gambar 3. Morfologi mikrokapsul minyak atsiri daun cengkeh dengan gelatin sebagai enkapsulan (konsentrasi 10\%) dengan perbandingan 1:10. a) 2000x, b)5000x

relatif tinggi bila dibandingkan dari perlakuan yang lain. Semakin tinggi konsentrasi gelatin yang digunakan sebagai enkapsulan, kelarutan mikrokapsul minyak atsiri daun cengkeh cenderung semakin rendah. Sedangkan semakin kecil rasio antara minyak cengkeh dengan gelatin, kelarutan mikrokapsul semakin tinggi.

Kelarutan suatu bahan dalam air dipengaruhi oleh kadar air bahan. Kadar air yang tinggi pada mikrokapsul akan menjadi sulit menyebar dalam air karena mikrokapsul cenderung lengket sehingga tidak terbentuk pori-pori, akibatnya mikrokapsul tidak mampu menyerap air dalam jumlah besar.

Total Minyak, Minyak Terperangkap (EO) dan Minyak Permukaan (SO) Mikrokapsul Minyak Atsiri Daun Cengkeh

Pada Gambar 2, menunjukkan total minyak, minyak terperangkap (Entrapped oil), dan minyak permukaan (surface oil) pada mikrokapsul. Total minyak mikrokapsul merupakan jumlah minyak atsiri daun cengkeh (eugenol) yang terdapat pada mikrokapsul, baik yang terdapat didalam maupun yang ada dipermukaan mikrokapsul. Total minyak pada mikrokapsul berkisar antara $0.4-1.1 \mathrm{mg} /$ $\mathrm{ml}$. Total minyak pada mikrokapsul yang paling tinggi diperoleh pada perlakuan 10\%, 1:10, yaitu $1.10 \mathrm{mg} / \mathrm{ml}$. Semakin kecil rasio antara minyak cengkeh dengan gelatin total minyak pada mikrokapsul cenderung menurun. Rendahnya nilai total minyak pada mikrokapsul diduga karena viskositas emulsi yang rendah sehingga pembentukan crust kurang sempurna dan terjadi keretakan pada mikrokapsul.

Minyak permukaan adalah minyak yang terdapat dipermukaan mikrokapsul. Minyak permukaan pada mikrokapsul berkisar antara $0.09-0.36 \mathrm{mg} / \mathrm{ml}$. Nilai minyak permukaan pada mikrokapsul yang relatif paling rendah diperoleh pada perlakuan 10\% 1:15, yaitu $0.09 \mathrm{mg} / \mathrm{ml}$. Semakin rendah konsentrasi gelatin $(5 \%)$ yang digunakan sebagai enkapsulan minyak permukaan pada mikrokapsul relatif lebih rendah. Kadar minyak permukaan yang rendah menunjukkan bahwa jumlah minyak 
yang berada pada permukaan mikrokapsul sedikit, sehingga bahan inti banyak yang terperangkap di dalam mikrokapsul.

Minyak terenkapsulasi (terperangkap) adalah minyak yang berada di dalam mikrokapsul, diperoleh dari selisih jumlah minyak total dengan minyak permukaan pada mikrokapsul. Minyak terperangkap pada mikrokapsul berkisar antara 0.14-0.87 $\mathrm{mg} / \mathrm{ml}$. Nilai minyak terperangkap pada mikrokapsul yang relatif paling rendah diperoleh pada perlakuan 5\% 1:20, yaitu 0.14 $\mathrm{mg} / \mathrm{ml}$. Semakin tinggi minyak atsiri daun cengkeh yang ditambahkan pada pembuatan mikrokapsul, minyak yang terperangkap pada mikrokapsul juga semakin banyak.

\section{Morfologi Mikrokapsul Minyak Atsiri Daun Cengkeh}

Bentuk partikel mikropartikel minyak atsiri daun cengkeh yang dikapsulkan menggunakan enkapsulan gelatin kulit kerbau bisa dilihat dengan menggunakan metode Scanning Electrom Microscope (SEM). Morfologi mikrokapsul minyak atsiri daun cengkeh bisa dilihat pada Gambar 3.

Ukuran mikrokapsul pada perlakuan 10\% dengan perbandingan 1:10 antara 3.84$13.29 \mu \mathrm{m}$. Pada konsentrasi gelatin dan rasio 1:10 diperoleh minyak terperangkap relative paling tinggi dibandingkan dengan perlakuan yang lain yaitu $0.87 \mathrm{mg} / \mathrm{ml}$. Bentuk mikrokapsul yang mengkerut dapat disebabkan oleh penguapan air yang cepat pada saat proses spray drying. Harris et al. (2010), bahwa mikrokapsul yang dihasilkan berbentuk bulat dan bergelombang yang disebabkan oleh penguapan pelarut yang cepat pada saat proses spray drying. Yuliani et al. (2007), menyatakan bahwa dinding mikrokapsul dapat mengalami peristiwa ballooning, yaitu peristiwa penggelembungan partikel mikrokapsul sebagai akibat pembentukan uap air didalamnya.

\section{SIMPULAN}

Karakteristik fisik dan kimia gelatin kulit kerbau, yaitu yield viskositas $4.8 \mathrm{cP}$, kekuatan gel $140.72 \mathrm{~g}$ Bloom, titik leleh $27.40^{\circ} \mathrm{C}$, kadar air $7.42 \%$, protein $89.90 \%$, lemak $0.04 \%$, dan abu $0.06 \%$. Karakteristik mikrokapsul minyak atsiri daun cengkeh dengan gelatin kulit kerbau sebagai enkapsulan, yaitu kelaru- tan kelarutan 79.72 , total minyak $1.10 \mathrm{mg} /$ $\mathrm{ml}$, minyak terperangkap $0.87 \mathrm{mg} / \mathrm{ml}$, dan minyak dipermukaan $0.23 \mathrm{mg} / \mathrm{ml}$. Morfologi mikrokapsul minyak atsiri daun cengkeh berbentuk oval dan tidak beraturan.

\section{DAFTAR PUSTAKA}

Alma, M, -H., Ertas, M, Nitz, -S., Kollmannsberger, -H., 2007, Chemical composition and content of essential oil from the bud of cultivated turkish clove (Syzygium aromaticum L.). Biores. 2, 265-269. https://bioresources.cnr. ncsu.edu/resources/chemical-composition-and-content-of-essential-oilfrom-the-bud-of-cultivated-turkishclove-syzygium-aromaticum-1/

Association of Official Analytical Chemists. 1995. Official Analytical Chemist Official Methods on Analysis. Gaithersburg, Maryland

British Standard 757. 1975. 'Sampling and Testing of Gelatin'. Dalam Imeson. Thikcening and Gelling Agents for Food. Academic Press, New York

Caliskan, -G., Dirim, S, - N., 2013. The Effects of the different drying conditions and the amounts of maltodextrin addition during spray drying of sumac extract. Food and Bioproducts Processing. 91, 539-548. https://doi.org/10.1016/j.fbp.2013.06.004

Calvo, -P., Castano, A, -L., Lozano, -M., Gonzales-Gomez, -D., 2012. Influence of the microencapsulation on the quality paramaters and shelf-life of extra-virgin olive oil encapsulated in the presence of BHT and different capsule wall component. Food Research International. 45, 256-261. https://doi. org/10.1016/j.foodres.2011.10.036

Chang, C, -P., Leung, T, -K., Lin, S, -M., Hsu, C, -C. 2006. Release properties on gelatin-gum arabic microcapsules containing camphor oil with added polystyrene. Colloids and Surfaces B: Biointerfaces. 50, 136-140. https://doi. org/10.1016/j.colsurfb.2006.04.008

Chen, -J., Jane, -J. 1994. Preparation of cold-watersoluble starches by alcoholic-alkaline treatment. Cereal Chemistry. 71, 618-622. https://www.aaccnet.org/publications/cc/ backissues/1994/Documents/71_618.pdf 
Dong, Z, -J., Xia, S, -Q., Hua, -S., Hayat, -K., Zhang, X, -M., Xu, S. -Y., 2008. Optimization of cross-linking parameters during production of transglutaminase-hardened spherical multinuclear microcapsules By complex coacervation. Colloids. Surf. B Biointerfaces. 63, 41-47. https://doi.org/10.1016/j.colsurfb.2007.11.007

Gharsallaoui, -A., Roudaut, -G., Chambin, O., Voilley, -A., Saurel, -R., 2007. Aplications of spray-drying in microencapulation of food ingredients: on overview. Food Research International. 40, 1107-1121. https://doi.org/10.1016/j. foodres.2007.07.004

Gomez, G, M, -C., Montero, -P., 2001. Extraction of gelatin from megrim (Lepidorhombus Boscii) skins with several organic acids. Journal of Food Science, 66, 213-216. http://dx.doi. org/10.1111/j.1365-2621.2001.tb11319.x

Gudmunsson, -M., Hafsteinsson, -H., 1997. Gelatin from cod skin as affected by chemical treatmens. Journal of Food Science. 62, 37-39. http://dx.doi. org/10.1111/j.1365-2621.1997.tb04363.x

Gu“lcin, -I., Elmastas, -M., Aboul-Enein, H, -Y., 2012. Antioxidant activity of clove oila powerful antioxidant source. Arabian Journal of Chemistry. 5, 489-499. https:/ / doi.org/10.1016/j.arabjc.2010.09.016

Harris, -R., Lecumberri, -E., Aparicio, I, -M., Mengibar, -M., Heras, -A., 2010. Chitosan nanoparticles and microspheres for the encapsulation of natural antioxidants extracted from ilex paraguariensis. Carbohydrate Polymers. 84, 803-806. https:/ / doi.org/10.1016/j.carbpol.2010.07.003

Hsieh, W, -C., Chang, C, -P., Gao, Y, -L. 2006. Controlled release properties of chitosan encapsulated volatile citronella oil microcapsules by thermal treatments. Colloids and Surfaces B: Biointerfaces. 53, 209-214. https://doi. org/10.1016/j.colsurfb.2006.09.008

Ivanovic, -J., Dimitrijevic-Brankovic, -S., Misic, -D., Ristic, -M., Zizovic, -I., 2013. Evaluation and improvement of antioxidant and antibacterial activities of supercritical extracts from clove buds. Journal of Functional Foods. 5, 416-423. https://doi.org/10.1016/j. jff.2012.11.014
Liu, -H., Li, -D., Guo, -S. 2008. Rheological properties of channel catfish (Ictalurus Punctaus) gelatin from fish skin preserved by different methods. LWT- Food Scince and Technology. 41, 1425-1430. https://doi.org/10.1016/j.lwt.2007.09.006

Petrovic, G, -M., Stojanovic, G, -S., Radulovic, N, -S., 2010. Encapsulation of cinnamon oil in $\beta$-cyclodextrin. Journal of Medicinal Plants Research. 14, 13821390. https://www.researchgate.net/ publication/224806621_Encapsulation_of_cinnamon_oil_in_I-cyclodextrin/download

Pranoto, -Y., Marseno, D, -W., Rahmawati, -H., 2011. Characteristics of gelatins extracted from fresh and sun-dried seawater fish skin in indonesia. International Food Research Journal. 18, 1335-1341. http://www.ifrj.upm.edu. my / 18\% 20(04)\% 202011/ (19)IFRJ2011-245.pdf

Soottitantawat, -A., Yoshii, -H., Futura, -T., Ohkawara, -M., Linko, -P., 2003. Microencapsulation by spray drying: influence of emulsion size on the retention of volatile compounds. Journal of Food Science. 68, 2256-2262. https:/ / doi. org/10.1111/j.1365-2621.2003.tb05756.x

Sutaphanit, -P., Chitprasert, -P., 2014. Optimisation of microencapsulation of holy basil essential oil in gelatin by response surface methodology. Food Chemistry. 150, 313-320. https://doi. org/10.1016/j.foodchem.2013.10.159

Ujwala, -S., Nagarsenker, -M., 2011. Microencapsulation of eugenol by gelatinsodium alginate complex coacervation. Indian Journal of Pharmaceutical Sciences. 73, 311-315. https://dx.doi. org/10.4103\%2F0250-474X.93524

Velasco, -J., Dobarganes, -C., Marques-Ruiz, -G., 2003. Variables affecting lipid oxidation in dried miencrocapsulated oils. Grasas y Aceites. 54, 304-314. https:// doi.org/10.3989/gya.2003.v54.i3.246

Yuliani, -S., Desmawarni, Harimurti, -N., Yuliani, S, -S., 2007. Pengaruh laju alir umpan dan suhu inlet spray drying pada karakteristik mikrokapsul oleoresin jahe. Jurnal Pascapanen. 4,1826. http://pascapanen.litbang.pertanian.go.id/assets/media/publikasi/ jurnal/j.Pascapanen.2007_1_3.pdf 